\title{
MEASUREMENT OF DNA DAMAGE, OXIDATIVE STRESS, AND GENE EXPRESSION OF $\beta$-CATENIN AND P53 GENES IN LIVER AND BRAIN OF MALE MICE RECEIVING MONOSODIUM L-GLUTAMATE MONOHYDRATE
}

\author{
NOHA IBRAHIM SAID SALEM ${ }^{1 *}$, HANAN R.H. MOHAMED ${ }^{2}$, AREEG MOHAMED ABD-ELRAZEK ${ }^{3}$
}

${ }^{1}$ Department of Zoology, Faculty of Science, Fayoum University, Fayoum, Egypt. ${ }^{2}$ Department of Zoology, Faculty of Science, Cairo University, Cairo, Egypt. ${ }^{3}$ Department of Physiology, National Organization for Drug Control and Research, Giza, Egypt. Email: nis00@fayoum.edu.eg

Received: 10 October 2019, Revised and Accepted: 09 May 2020

ABSTRACT

objective: Monosodium L-glutamate (MSG) monohydrate is a widespread nutritional additive and flavoring agent frequently consumed all over the world. In this study, we investigate the action of daily oral intake of MSG monohydrate in vivo using mammalian systems.

Methods: Mice divided as follows: Group I (normal control), Group II, and Group III treated with MSG for 2 and 4 weeks, respectively. Brain and liver dissected out for the detection of fragmented DNA, DNA damage, and assay of oxidative stress markers. Moreover, expression levels of ß-Cat and p53 genes were measured by a real-time quantitative polymerase chain reaction.

Results: The results showed a significant difference in MSG treated group at the two-time intervals than the control one regarding parameters of oxidative stress reflected by the significant rise of malondialdhyde (MDA), nitric oxide (NO) and oxidized glutathione (GSSG) and these were accompanied by a significant decline in glutathione (GSH) and a ratio of oxidized and reduced GSH (GSH/GSSG) in both tissues. Significant elevation of laddered DNA and oxidative DNA damage was observed in groups treated with MSG. In addition to a significant decline in gene expression of $\beta$-Catenin in liver and brain tissues with elevations in the gene expression of p53 in the brain. Furthermore, the p53 gene in liver tissue was significantly upregulated in mice administered MSG for 15 days and was down-regulated after 30 days of MSG intake compared with the control.

Conclusion: According to our results, oral consumption of MSG leads to oxidative stress-mediated DNA damage and apoptosis.

Keywords: Monosodium L-glutamate monohydrate, Oxidative stress, DNA damage; DNA fragmentation, Quantitative polymerase chain reaction, Mice.

(c) 2020 The Authors. Published by Innovare Academic Sciences Pvt Ltd. This is an open access article under the CC BY license (http://creativecommons. org/licenses/by/4. 0/) DOI: http://dx.doi.org/10.22159/ajpcr.2020.v13i7.36019

\section{INTRODUCTION}

Vast population growth and rapid lifestyle have resulted in a marked increase in the demand for packaged food products. The great dependence on these packaged and preserved foods resulted in deleterious effects caused by the excessive use of food enhancers and food additives found in this food. Among the deleterious effects caused by the regular use of these food additives and packaged food are genotoxicity, mutagenicity, hypersensitivity, and obesity. Many food additives, even, have been banned from use due to their toxicity.

Monosodium L-glutamate (MSG) monohydrate, the non-essential amino acid, and L-glutamic acid sodium salt are the result of the hydrolysis of vegetable proteins. A widespread and regularly used food additive added to improve nutritional quality and to make the food more appealing. MSG is also produced naturally in the body and has a fundamental role in human metabolism. The average consumption of MSG is estimated to be $0.3-1.0 \mathrm{~g}$ daily in industrialized countries, but it can be exceeded depending on the number of taken food items [1]. Some investigations on the safety of the use of MSG revealed incompatible results. The USFood and Drug Administration has confirmed that the use of MSG is safe for humans and classified MSG as GRAS lists of food. These safety aspects were also confirmed by the American Medical Association, the Joint FAO/WHO (1988), Expert Committee on Food Additives, and the Scientific Committee for Food of the European Union (SCF, 1991). On the other hand, many studies revealed that MSG induced toxicity as well [2-6]. MSG also reported to cause obesity and induces metabolic disorders associated with oxidative stress [7].

Moreover, many reports revealed the adverse impact of using MSG as a food additive [2,8-10]. Daily consumption of MSG by humans, especially children, delaying their cognitive skills, and causing learning difficulties [11,12]. MSG may cause neurotoxicity, depression [13], and neurodegenerative diseases [14]. Furthermore, it induces hepatotoxicity in adult rats and causes liver and kidney damage. Furthermore, the genotoxic potential of MSG was investigated in the Allium cepa assay [15] and cultured human lymphocytes [16].

Since all kinds of the literature study, the effect of MSG in vitro or/and no literature found regarding the studies of the effect of MSG in vivo at the molecular level in liver and brain tissues. Hence, the present study was established to evaluate whether MSG intake can result in DNA damage, apoptosis induction, and oxidative stress using the comet assay, laddered DNA fragmentation, and oxidative stress biomarkers, respectively. In addition, real-time quantitative polymerase chain reaction (qPCR) carried out to measure the expression levels of p53 as well as $\beta$-Cat genes in the liver and brain tissues.

\section{METHODS}

Experimental groups and animals

The cancer research institute, Egypt, supplied 30 adult male (CD-1) mice weighting $(25 \pm 2 \mathrm{~g})$. They were housed in clean and properly ventilated cages under standard conditions (12-h dark/night), which were given free access to food and water, and left for 1 week to be accommodated with laboratory conditions before beginning treatment. All experimental procedures and animal maintenance were performed at the cancer research institute and approved by the ethical committee of NODCAR, Egypt. The mice were divided into three different groups $(\mathrm{n}=10)$ as follows:

Group (1) normal control group, in which each animal was given saline daily by gavage; Group (2), in which each mouse was administrated a 
daily oral dose of MSG $0.3 \mathrm{mg} \mathrm{MSG} / \mathrm{g}$ body weight $\left(1 / 50\right.$ times $<\mathrm{LD}_{50}$ that was estimated to be $15,800 \mathrm{mg} / \mathrm{kg}$ in rats and mice) dissolved in saline by gavage for 2 weeks [17]; and Group (3), in which each mouse received the same dose of MSG as above continuously for 4 consecutive weeks [18]

\section{Chemicals}

MSG monohydrate (C5H9NO4.Na) was obtained from FLUKA Chemical Co. (USA) and liquefied in distilled water. Other common chemical reagents used in this study were of analytical grades and were supplied by Sigma Chemical Co. (St. Louis, MO, USA).

\section{Collection of samples}

At the end of the study period, mice were sacrificed. The brain and liver of each of the animals were dissected out and kept at $-20^{\circ} \mathrm{C}$.

\section{Oxidative stress parameters}

Determination of malondialdehyde (MDA) by HPLC

1, 1, 3, 3-tetraethoxy propane purchased from Sigma (St. Louis, MO, USA), a precursor of MDA, was used as a standard for this assay [19]. MDA concentration still issues as the most important index of lipid peroxidation.

Determination of GSH and GSSG by HPLC

The thiols of oxidized and reduced glutathione (GSSH and GSH) detected by HPLC [20].

\section{Determination of nitrite and nitrate by HPLC}

A standard mixture of nitrite and nitrate sodium as used to determine the retention times and separation of the peaks at $230 \mathrm{~nm}$ [21].

\section{Single cell gel electrophoresis (comet assay)}

Comet assay was carried out to measure the degree of DNA damage in the brain and liver tissues according to the protocol described by Tice et al. [22]. The samples of liver and brain were flushed out into cold mincing solution. Cell suspension $(10 \mu \mathrm{l})$ of each sample $(1 \times 104$ cells $)$,

Table 1: Sequences of the used primers in q PCR

\begin{tabular}{ll}
\hline Gene & Sequence \\
\hline P53 & $\begin{array}{l}\text { sense: 5'-ANCCATCGGAGCAGCCCTCAT-3' } \\
\text { antisense: 5'-TACTCTCCTCCCCTCAATAAG-3' }\end{array}$ \\
$\beta$-Cat & $\begin{array}{l}\text { Sense: 5'GCTGACCTGATGGAGTTGGA-3' } \\
\text { antisense: 5'-GCTACTTGCTCTTGCGTGAA-3' }\end{array}$ \\
$\beta$-actin & $\begin{array}{l}\text { Sense: 5'-TCA CCC ACA CTG TGC CCA TCT ACGA-3' } \\
\text { antisense: 5'-GGA TGC CAC AGG ATT CCA TACCCA-3' }\end{array}$ \\
\hline
\end{tabular}

mixed with $0.5 \%$ low melting agarose, spread uniformly on a slide fully frosted and coated with normal melting point agarose (1\%). Slides were left until agarose is hardening then incubated in cold lysis buffer at $4^{\circ} \mathrm{C}$ for 1 day in darkness. The slides were then transferred on a horizontal electrophoresis unit and incubated in freshly prepared electrophoresis buffer ( $300 \mathrm{mM}$ sodium hydroxide, and $1 \mathrm{mM}$ EDTA, $\mathrm{pH}>13.0$ ) for 20 min to allow unwinding of DNA helix. The samples undergo electrophoresis for $30 \mathrm{~min}$ at $25 \mathrm{~V}$ and $300 \mathrm{~mA}$. The slides were then dipped in neutralizing buffer ( $0.4 \mathrm{M}$ Tris- $\mathrm{HCl}, \mathrm{PH} 7.4)$ and dehydrated in $100 \%$ cold ethanol for $10 \mathrm{~min}$ and allowed to dry at room temperature. Each slide was stained with ethidium bromide $(20 \mu \mathrm{g} / \mathrm{mL})$ immediately before imaging. Two slides per sample were examined, and 50 isolated cells per animal were randomly scored for comet tail length, \% DNA in tail, and tail moment using COMETSCORE software as previously defined by Olive and Banath [23] using COMETSCORE software.

\section{Laddered DNA fragmentation assay}

To assess apoptotic DNA damage in the liver and brain tissues, laddered DNA fragmentation was conducted [24]. Briefly, tiny fragments of tissues were gently homogenized and lysed in sodium dodecyl sulfate-TE lysis buffer. The samples were incubated with RNAse $\left(1 \mathrm{~h}\right.$ at $\left.37^{\circ} \mathrm{C}\right)$, then with proteinase $\mathrm{K}$ (overnight at $50^{\circ} \mathrm{C}$ ). A mixture of ammonium acetate and isopropyl alcohol was used for DNA extraction and precipitation. Finally, the extracted DNA was run on agarose gel (1\%) containing ethidium bromide stain at $70 \mathrm{~V}$, examined under ultraviolet trans-illuminator, and then captured.

\section{Quantification of $\mathrm{p} 53$ and $\beta$-Cat genes expression}

The expression levels of p53 and $\beta$-Cat genes in the liver and brain were carried out by qPCR. Total RNA was extracted according to the instruction of the manufacture of GeneJET RNA Purification Kit (Thermo Scientific, USA) with adding DNAse I to remove the DNA residue. The concentration and purity of the extracted RNA were determined by the NanoDrop device at $260 / 280 \mathrm{~nm}$. Then, the resultant purified RNA samples were converted to cDNA using RevertAid First Strand cDNA Synthesis Kit (Thermo Scientific, USA) as described by the manufacturer.

Finally, p53 and $\beta$-Cat genes were amplified using the previously designed sets of primers as shown in Table 1 [25-27]. A PCR reaction mixture was prepared for each gene separately using $12 \mu \mathrm{L}$ of $2 \mathrm{x}$ SYBR Green master mix (Thermo Scientific, USA). The qPCR reaction was performed using the 7500 Fast system (Applied Biosystem 7500, Clinilab, Egypt), starting at $95^{\circ} \mathrm{C}$ (denaturation temperature) for 15 min followed by 35 cycles at $95^{\circ} \mathrm{C}$ for $15 \mathrm{~s}$, annealing for $30 \mathrm{~s}$ at $58^{\circ} \mathrm{C}$ (for P53), or $55^{\circ} \mathrm{C}$ (for $\beta$-Cat). The extension then performed at $72^{\circ} \mathrm{C}$ for $1 \mathrm{~min}$; then, the amplified genes expression was standardized using the $\beta$-actin gene (housekeeping gene).

Table 2: The effect of monosodium glutamate administration for 15 and 30 days on oxidative stress parameter in liver tissues

\begin{tabular}{llllll}
\hline Groups & $\begin{array}{l}\text { MDA } \\
\text { (nmol/g.tissue) }\end{array}$ & $\begin{array}{l}\text { No } \\
\text { (nmol/0.1g.tissue) }\end{array}$ & $\begin{array}{l}\text { GSH } \\
\text { ( } \boldsymbol{\mu m o l} / \mathbf{g} \text {. wet tissue) }\end{array}$ & $\begin{array}{l}\text { GSSG } \\
\text { ( } \boldsymbol{\mu m o l} / \text { g. wet tissue) }\end{array}$ & GSH/GSSG \\
\hline Control & $27.92 \pm 0.06$ & $76.61 \pm 0.18$ & $28.7 \pm 0.15$ & $1.62 \pm 0.04$ & $17.68 \pm 0.06$ \\
MGS (15Days) & $36.56 \pm 0.04^{\mathrm{a}}$ & $94.05 \pm 0.28^{\mathrm{a}}$ & $22.7 \pm 0.27^{\mathrm{a}}$ & $2.49 \pm 0.08^{\mathrm{a}}$ & $9.48 \pm 0.04^{\mathrm{a}}$ \\
MGS (30Days) & $34.67 \pm 0.06^{\mathrm{a}}$ & $84.37 \pm 0.11$ & $19.2 \pm 0.25^{\mathrm{a}}$ & $2.34 \pm 0.08^{\mathrm{a}}$ & $8.19 \pm 0.02^{\mathrm{a}}$ \\
\hline
\end{tabular}

The data represented by mean \pm SEM ( $n=10),{ }^{a} \mathrm{p}$ significant difference from control at $\mathrm{p}<0.05$, ${ }^{\mathrm{b}} \mathrm{p}$ significant difference between MGS (15 Days) and MGS (30 Days) groups at $\mathrm{p}<0.05$

Table 3: The effect of monosodium glutamate administration for 15 and 30 days on oxidative stress parameter in brain tissues

\begin{tabular}{|c|c|c|c|c|c|}
\hline Groups & $\begin{array}{l}\text { MDA } \\
\text { (nmol / g.tissue) }\end{array}$ & $\begin{array}{l}\text { NO } \\
\text { (nmol/g.tissue) }\end{array}$ & $\begin{array}{l}\text { GSH } \\
(\mu \mathrm{mol} / \mathrm{g} \text {. wet tissue })\end{array}$ & $\begin{array}{l}\text { GSSG } \\
(\mu \mathrm{mol} / \mathrm{g} \text {. wet tissue })\end{array}$ & GSH/GSSG \\
\hline Control & $13.41 \pm 0.005$ & $38.39 \pm 0.06$ & $9.7 \pm 0.04$ & $0.29 \pm 0.001$ & $33.4 \pm 0.11$ \\
\hline MGS (15DAYS) & $16.73 \pm 0.03^{a}$ & $46.21 \pm 0.11^{a}$ & $7.7 \pm 0.01^{\mathrm{a}}$ & $0.43 \pm 0.002^{\mathrm{a}}$ & $18.16 \pm 0.07^{\mathrm{a}}$ \\
\hline MGS (30DAYS) & $20.57 \pm 0.03^{\mathrm{ab}}$ & $40.11 \pm 0.02^{\mathrm{b}}$ & $6.5 \pm 0.008^{a}$ & $0.42 \pm 0.001^{\mathrm{a}}$ & $15.5 \pm 0.04^{\mathrm{a}}$ \\
\hline
\end{tabular}

The data represented by mean \pm SEM ( $n=10)$, ${ }^{\mathrm{p}}$ significant difference from control at $\mathrm{p}<0.05,{ }^{\mathrm{b}} \mathrm{p}$ significant difference between MGS (15Days) and MGS (30 Days) groups at $\mathrm{p}<0.05$ 


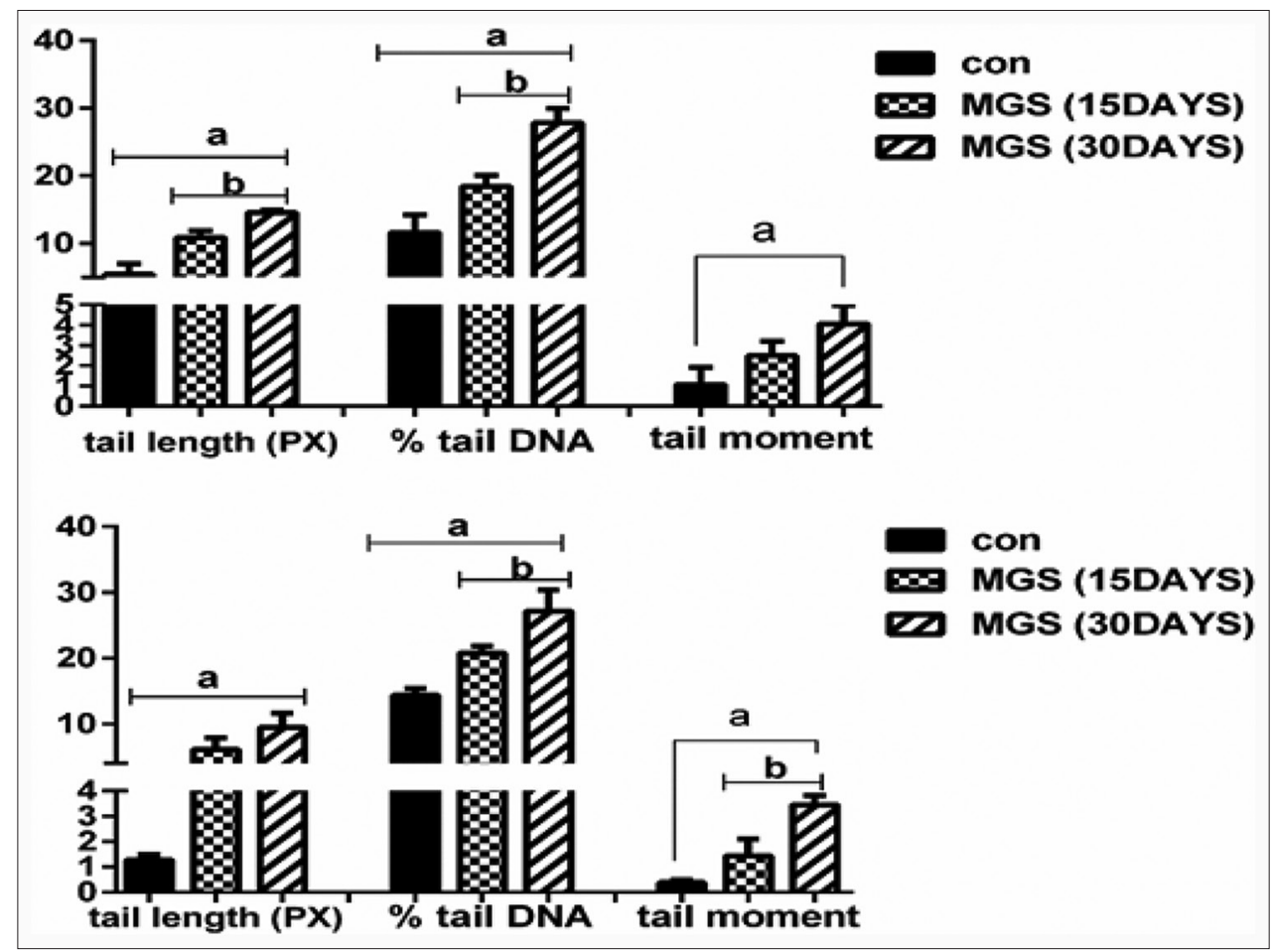

Fig. 1: DNA damage induction by oral administration of MSG for 15 and 30 days in brain and liver tissues expressed by comet assay, the data represented by mean \pm SEM $(n=10)$, ${ }^{a} p$ significant difference from control at $p<0.05$, ${ }^{b} p$ significant difference between MSG (15 Days) and MSG (30 Days) groups at $\mathrm{p}<0.05$

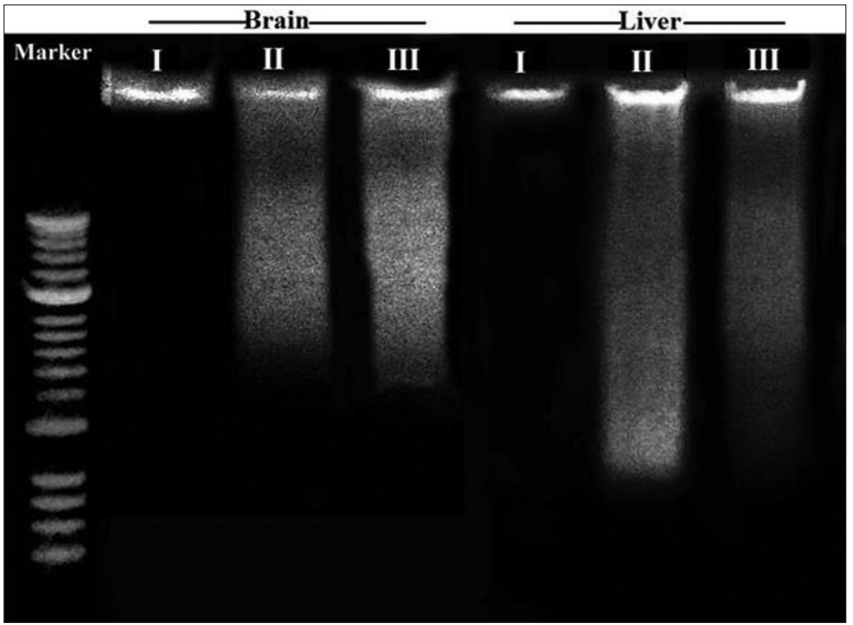

Fig. 2: Pattern of genomic DNA electrophoresed on agarose gel and stained with ethidium bromide of mice administered MSG for 15 (II) or 30 (III) days with respect to control mice (I)

\section{Statistical analysis}

Statistical analysis of the obtained data was performed using the Statistical Package Software System (SPSS) version 25.

Significant differences among means were evaluated using one-way ANOVA, and the difference between different groups was estimated through Turkey's multiple comparisons post hoc.

\section{RESULTS}

Effects of MSG on oxidative stress parameters

The data represented in Table 2 showed that treatment with MSG for 15 days caused a remarked elevation $(p<0.05)$ in hepatic MDA, NO, and, in GSSG while showing significant $(\mathrm{p}<0.05)$ reduction in hepatic GSH level and GSH/GSSG ratio. The prolonged treatment for 30 days showed slight enhancement in all parameters with no significant $(p>0.05)$ difference between the two intervals except in NO that the maximum effect was at the first interval.

Furthermore, the administration of MSG for 15 and 30 days caused a significant increase in cerebral MDA and NO in a time-dependent manner. The MSG treatment likewise caused significant $(p<0.05)$ elevation in cerebral GSSG, while showing a significant reduction in cerebral GSH level, and GSH and GSSG ratio without significant difference between the two experimental intervals (Table 3).

Single cell gel electrophoresis (Comet assay)

As shown in (Fig. 1), oral administration of MSG resulted in statistically significant increases $(\mathrm{p}<0.05)$ in the tail length, \%DNA in tail, and tail moment in a time-dependent manner compared to those of the negative control group in both the liver and brain tissues.

\section{Laddered DNA fragmentation}

Like the results of the comet assay, the electrophoresed pattern of genomic DNA on the agarose gel revealed the induction of dramatic DNA damage by MSG in both the liver and brain tissue. This is manifested by the smeared fragmentized pattern of genomic DNA of the mice that administered MSG compared to the intact pattern of the negative control genomic DNA at the two experimental intervals (Fig. 2).

Expression levels of p53 and $\beta$-Cat genes

In the brain tissue, oral administration of MSG caused statistically significant $(\mathrm{p}<0.05)$, elevation in the expression level of P53 gene in a time-dependent manner, while the p53 gene in liver tissue was significantly $(\mathrm{p}<0.05)$ unregulated in mice orally administered MSG for 15 days and was downregulated after 30 days of MSG administration compared with the negative control level, as shown in Fig. 3.

On the other hand, the expression level of the $\beta$-Cat gene was significantly $(\mathrm{p}<0.05)$ decreased in the liver and brain tissues of mice 


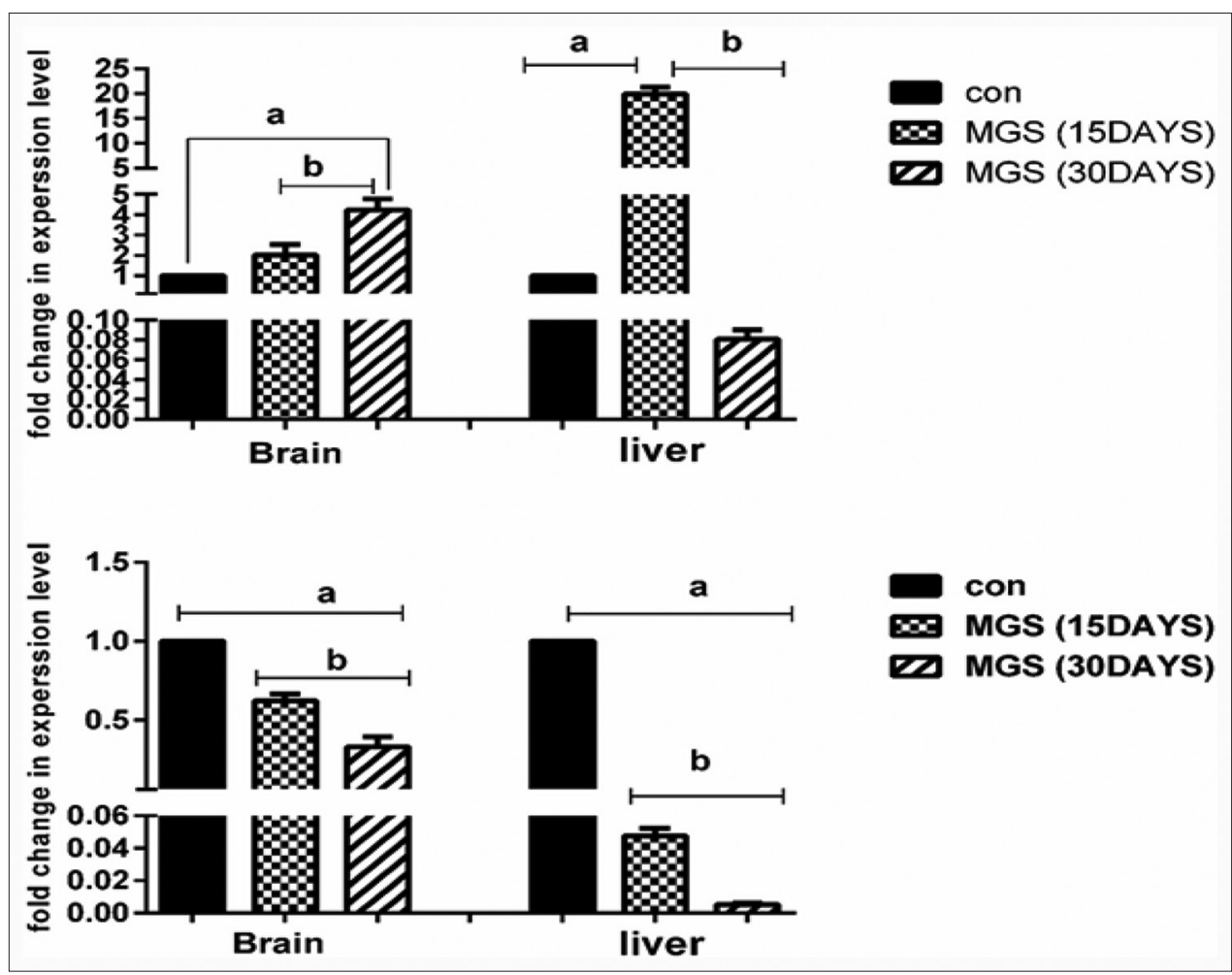

Fig. 3: The effect of MSG administration for 15 and 30 days on the level of P53 and ß-Cat expression in brain and liver tissues. the data represented by mean \pm SEM $(n=10)$, ${ }^{a} p$ significant difference from control at $p<0.05$, ${ }^{b}$ significant difference between MSG (15 Days) and MSG (30 Days) groups at $\mathbf{p}<\mathbf{0 . 0 5}$

orally administered MSG for 15 or 30 days in a time-dependent manner as compared to the negative control (Fig. 3).

\section{DISCUSSION}

Monosodium L-glutamate monohydrate (MSG) is one of the most broadly used food enhancer for its UMAMI taste [28]. We extensively eat it in many commercial packed food, restaurant, and household cooking without defining its safe limit. Despite its worldwide use as a food enhancer, there are considerable reports that confirm the toxicity of MSG to humans and experimental animals $[29,30]$. Previously, it was discovered to induce adverse effects to many body organs including the liver, thymus, brain, kidneys, and gonads of many experimental animals $[2,31]$.

In our experiment, MSG was administrated orally by gavage because this gives more reproducible responses and attains higher plasma levels than when it is mixed with food. As the liver was responsible for detoxification and metabolism of food so, it is directly influenced by toxic substances or their metabolites as MSG. Furthermore, MSG dissociates inside the body into glutamate and sodium ions. Glutamate is one of the amino acids that occur naturally in the brain so; we studied the impact of MSG intake mainly in these two tissues.

Our data showed that daily oral MSG uptake at the two-tested duration resulted in increased levels of lipid peroxidation end-products (MDA), NO, and GSSG in the liver and brain. This is accompanied by a significant decrease in the level of GSH, as well as, GSH/GSSG ratio. The observed elevation of oxidative stress markers accompanied by MSG intake is due to increased generation of reactive oxygen species (ROS) that causes lipid peroxidation. The same results have been found by earlier workers [9, 32-37]. The excessive production or a decreased elimination of free radicals, especially oxygen radicals, and other ROS are the direct causes of oxidative stress in cells [38]. Several studies have indicated the role of oxidative stress in the toxicity of MSG [35-37]. Therefore, ROS can be produced as a result of glutamate metabolism resulted from chronic MSG intake and might have caused GSH depletion, as well as, GSH/GSSG ratio. Depletion of glutathione is an indicator of tissue damage. Thus, depletion of tissue level of GSH as well as, GSH/GSSG ratio accompanied MSG-induced lipid peroxidation. GSH is a fundamental endogenous antioxidant, scavenges reactive oxygen intermediates and reserves the intracellular redox balance, and prevents oxidative insult of tissues [39]. Elevation of oxidative stress markers accompanied by MSG treatment is strong indications of oxidative stress induced by it in liver and brain tissues. The brain is from organs that exposed to free radical damage because it has a high rate of oxidative metabolic activity, high content of polyunsaturated fatty acids, and low levels of antioxidant enzymes [40]. MSG was reported to exhibit neurotoxicity resulting in damage to brain cells [36]. Many studies have explained damage in the brain due to glutamate-induced oxidative damage where glutamate receptors, $\alpha$-ketoglutarate dehydrogenase, and cystineglutamate anti-porter are the key players [41,42]. The evidence for DNA damage in response to MSG was obtained using the comet assay. Increased generation of ROS in the cells produced DNA strand break. This confirms our results that reported the significant induction of DNA damage by MSG administration as manifested by the increases in all the studied parameters of comet assay in a time-dependent manner. Recent studies have demonstrated that ROS play essential role in apoptosis initiation. This explains the higher intensity of fragmentized DNA observed on an agarose gel in MSG groups compared to the intact DNA of the negative control group in both the liver and brain tissues. Similar findings were confirmed by Farombi et al. [35] who observed the potential genotoxic effect of dietary MSG (4 mg/g. BW, intraperitoneally) in rats. The genotoxic effect was also confirmed by increased frequencies of micronucleus in rat bone marrow cells in addition to the induction of chromosome aberrations, sister-chromatid exchanges, and micronucleus in cultured human lymphocytes. Pavlovic et al. [31] reported that a significant increase in oxidative stress might induce DNA damage that ultimately leads to cell death.

P53-protein acts as a DNA sequence-specific transcription factor regulating and activating the expression of a range of target genes in 
response to genotoxic stress. This in turn initiates a cascade of signal transduction pathways leading to altered cellular responses including cell-cycle arrest and apoptosis [43].

To further shed light on the mechanism of the apoptotic DNA damage demonstrated in MSG administered groups, the degree of expression of P53 and $\beta$-Cat genes were measured in both liver and brain tissues. Under normal circumstances, P53 is most likely latent, due to its rapid ubiquitination and proteolytic degradation. However, a variety of conditions can lead to rapid stabilization and activation of P53 including DNA damage, spindle cleavage, depletion of ribonucleotides, hypoxia, heat shock, and exposure to nitric oxide [44,45]. As a result, our discovery of p53 up regulation can be attributed to genotoxic stress induced by MSG in the mice liver and brain tissues. Furthermore, the apparent concurrent down expression of $\beta$-Cat gene because of elevated expression of the P53 gene facilitates P53 mediated apoptosis. These findings support the discovery of Sadot and his colleagues, that increasing expression levels of the p53 gene down regulates $\beta$-Cat expression and decreases $\beta$-Cat level by accelerating the degradation of $\beta$-Cat [46].

On the other hand, down regulation of P53 expression demonstrated in the liver of mice administered MSG for four weeks can be attributed to the high regenerative capacity of liver tissue, as well as, inhibition of P53 activity is absolutely essential at the initial stage of liver regeneration to maintain durability and ensure the fidelity of regeneration process [47].

\section{CONCLUSION}

We demonstrated that the administration of MSG at a dose of $0.3 \mathrm{mg} / \mathrm{g}$ BW for 2 and 4 weeks induced oxidative stress and apoptotic DNA damage in the liver and brain tissues of mice. Hence, its intake should be reduced for cases of liver or brain disorders, while attention should be paid for its usage as a flavor enhancer.

\section{AUTHORS CONTRIBUTIONS}

Noha I. Said designed the study and interpreted the results. Areeg M. Abd-Elrazek and Hanan R.H. Mohamed performed the experiments, interpreted the results and analyzed the data. Noha I. Said, Areeg M. Abd-Elrazek, and Hanan R.H. Mohamed wrote and revised the manuscript.

\section{ETHICS APPROVAL AND CONSENT TO PARTICIPATE}

All animal experimentation protocols carried out under the supervision and approval of the Ethics Committee of NODCAR (NODCAR/II/57/20), Egypt.

\section{AVAILABILITY OF DATA AND MATERIALS}

All data are available with the corresponding author.

\section{DISCLOSURE OF INTEREST}

All authors declare no conflicts of interest related to the present work.

\section{REFERENCES}

1. Geha RS, Beiser A, Ren C, Patterson R, Greenberger PA, Grammer LC, et al. Review of alleged reaction to monosodium glutamate and outcome of a multicenter double-blind placebo-controlled study. J Nutr 2000;130:1058S-62.

2. OnyemaOO, Farombi EO, Emerole GO, Ukoha AI, Onyeze GO. Effect of Vitamin $\mathrm{E}$ on monosodium glutamate induced hepatotoxicity and oxidative stress in rats. Indian J Biochem Biophys 2006;43:20-4.

3. BojanićV, Bojanić Z, Najman S, Savić T, Jakovljević V, Najman S, et al. Diltiazem prevention of toxic effects of monosodium glutamate on ovaries in rats. Gen Physiol Biophys 2009;28:149-54.

4. Abass MA, El-Haleem MR. Evaluation of monosodium glutamate induced neurotoxicity and nephrotoxicity in adult male albino rats. J Am Sci 2011;7:264-70.

5. Ebaid H, Tag H. Monosodium glutamate toxic effect on spleen structure and potentiality of recovery in adult albino rats. Egypt Acad J Biol Sci B Zool 2012;4:1-8.

6. Khatab HA, Elhaddad NS. Evaluation of mutagenic effects of monosodium glutamate using Allium cepa and antimutagenic action of Origanum majorana L. and Ruta chalepensis medical plants. Biotechnol J Int 2015;8:1-11.

7. Abuzaid AS, Iskandar EY, Kurniati NF, Adnyana IK. Preventive effect on obesity of mangosteen (Garcinia mangostana L.) pericarp ethanolic extract by reduction of fatty acid synthase level in monosodium glutamate and high-calorie diet-induced male Wistar rats. Asian J Pharm Clin Res 2016;9:3-6.

8. Tawfik MS, Al-Badr N. Adverse effects of monosodium glutamate on liver and kidney functions in adult rats and potential protective effect of Vitamins C and E. Food Nutr Sci 2012;3:651-9.

9. Ortiz GG, Bitzer-Quintero OK, Zárate CB, Rodríguez-Reynoso S, Larios-Arceo F, Velázquez-Brizuela IE, et al. Monosodium glutamateinduced damage in liver and kidney: A morphological and biochemical approach. Biomed Pharmacother 2006;60:86-91.

10. Pavlović V, Cekić S, Kocić G, Sokolović D, Zivković V. Effect of monosodium glutamate on apoptosis and $\mathrm{Bcl}-2 / \mathrm{Bax}$ protein level in rat thymocyte culture. Physiol Res 2007;56:619-26.

11. Appaiah KM. Monosodium glutamate in foods and its biological effects. In: Ensuring Global Food Safety. Ch. 13. United States: Academic Press; 2010. p. 217-26.

12. Plaitakis A, Shashidharan P. Glutamate transport and metabolism in dopaminergic neurons of substantia nigra: Implications for the pathogenesis of Parkinson's disease. J Neurol 2000;247:II25-35.

13. Sriram BS, Ravichandra V. An experimental study evaluating the influence of quercetin on monosodium glutamate-induced depression in swiss albino male mice. Asian J Pharm Clin Res 2019;12:292-4.

14. Lau A, Tymianski M. Glutamate receptors, neurotoxicity and neurodegeneration. Pflügers Arch Eur J Physiol 2010;460:525-42.

15. Adeyemo OA, Farinmade AE. Genotoxic and cytotoxic effects of food flavor enhancer, monosodium glutamate (MSG) using Allium cepa assay. Afr J Biotechnol 2013;12:1459-66.

16. Ataseven N, Yüzbaşioğlu D, Keskin AÇ, Ünal F. Genotoxicity of monosodium glutamate. Food Chem Toxicol 2016;91:8-18.

17. Hashem HE, El-Din Safwat MD, Algaidi S. The effect of monosodium glutamate on the cerebellar cortex of male albino rats and the protective role of Vitamin C (histological and immunohistochemical study). J Mol Histol 2012;43:179-86

18. Khalaf HA, Arafat EA. Effect of different doses of monosodium glutamate on the thyroid follicular cells of adult male albino rats: A histological study. Int J Clin Exp Pathol 2015;8:15498-510.

19. Karatepe M. Simultaneous determination of ascorbic acid and free malondialdehyde in human serum by HPLC-UV. LCGC Asia Pac 2004;7:7-9.

20. Jayatilleke E, Shaw S. A high-performance liquid chromatographic assay for reduced and oxidized glutathione in biological samples. Anal Biochem 1993;214:452-7.

21. Papadoyannis IN, Samanidou VF, Nitsos CC. Simultaneous determination of nitrite and nitrate in drinking water and human serum by high performance anion-exchange chromatography and Uv detection. J Liq Chromatogr Relat Technol 1999;22:2023-41.

22. Tice RR, Agurell E, Anderson D, Burlinson B, Hartmann A, Kobayashi $\mathrm{H}$, et al. Single cell gel/comet assay: Guidelines for in vitro and in vivo genetic toxicology testing. Environ Mol Mutagen 2000;35:206-21.

23. Olive PL, Banáth JP. Multicell spheroid response to drugs predicted with the comet assay. Cancer Res 1997;57:5528-33.

24. Sriram MI, Kanth SB, Kalishwaralal K, Gurunathan S. Antitumor activity of silver nanoparticles in Dalton's lymphoma ascites tumor model. Int J Nanomed 2010;5:753-62.

25. Gutierrez MI, Bhatia K, Siwarski D, Wolff L, Magrath IT, Mushinski JF, et al. Infrequent p53 mutation in mouse tumors with deregulated myc. Cancer Res 1992;52:1032-5.

26. Shimada I, Takahashi H, Nakanishi T, Kami K, Arata Y. A novel NMR method for determining the interfaces of large protein-protein complexes. Nat Struct Biol 2000;7:220-3

27. Oh SW, Harris JA, Ng L, Winslow B, Cain N, Mihalas S, et al. A mesoscale connectome of the mouse brain. Nature 2014;508:207-14.

28. Bhattacharya T, Bhakta A, Ghosh SK. Long term effect of monosodium glutamate in liver of albino mice after neo-natal exposure. Nepal Med Coll J 2011;13:11-6.

29. Husarova V, Ostatnikova D. Monosodium glutamate toxic effects and their implications for human intake: A review. JMED Res 2013;2013:1-12.

30. Umukoro S, Oluwole GO, Olamijowon HE, Omogbiya AI, Eduviere AT. 
Effect of monosodium glutamate on behavioral phenotypes, biomarkers of oxidative stress in brain tissues and liver enzymes in mice. Artic World J Neurosci 2015;5:339-49.

31. Pavlovic V, Pavlovic D, Kocic G, Sokolovic D, Jevtovic-Stoimenov T, Cekic S, et al. Effect of monosodium glutamate on oxidative stress and apoptosis in rat thymus. Mol Cell Biochem 2007;303:1610-6.

32. Diniz YS, Fernandes AA, Campos KE, Mani F, Ribas BO, Novelli EL. Toxicity of hypercaloric diet and monosodium glutamate: Oxidative stress and metabolic shifting in hepatic tissue. Food Chem Toxicol 2004;42:313-9.

33. Onaolapo OJ, Aremu OS, Onaolapo AY. Monosodium glutamateassociated alterations in open field, anxiety-related and conditioned place preference behaviours in mice. Naunyn Schmiedebergs Arch Pharmacol 2017;390:677-89.

34. Thomas M, George S. Effect of Piper longum Linn, in monosodium glutamate toxicity in rats. Indian J Anim Sci 2010;80:857-63.

35. Farombi O, Onyema OO, Farombi E. Monosodium glutamate-induced oxidative damage and genotoxicity in the rat: Modulatory role of Vitamin C, Vitamin E and quercetin. Hum Exp Toxicol 2006;25:251-9.

36. Eweka AO, Igbigbi PS, Ucheya RE. Histochemical studies of the effects of monosodium glutamate on the liver of adult Wistar rats. Ann Med Health Sci Res 2011;1:21-30.

37. Abdel-Aziem SH, Abd El-Kader HA, Ibrahim FM, SharafHA, El Makawy AI. Evaluation of the alleviative role of Chlorella vulgaris and Spirulina platensis extract against ovarian dysfunctions induced by monosodium glutamate in mice. J Genet Eng Biotechnol 2018;16:653-60.

38. Bashan N, Kovsan J, Kachko I, Ovadia H, Rudich A. Positive and negative regulation of insulin signaling by reactive oxygen and nitrogen species. Physiol Rev 2009;89:27-71.

39. Sankar M, Rajkumar J, Sridhar. Effect of heptoplus on isoniazid and rifampicin induced hepatotoxicity in liver cell lines. Int J Pharm Pharm Sci 2015;7:215-9.

40. Shulman RG, Rothman DL, Behar KL, Hyder F. Energetic basis of brain activity: Implications for neuroimaging. Trends Neurosci 2004;27:489-95.

41. Murphy BF, Saunders JR, O'Bryan MK, Kirszbaum L, Walker ID, D'Apice AJ. SP-40,40 is an inhibitor of C5b-6-initiated haemolysis. Int Immunol 1989;1:551-4.

42. Zündorf G, Kahlert S, Bunik VI, Reiser G. $\alpha$-Ketoglutarate dehydrogenase contributes to production of reactive oxygen species in glutamate-stimulated hippocampal neurons in situ. Neuroscience 2009;158:610-6.

43. Vinutha K, Vidya SM, Kumari SN, Sanjeev G, Nagendra HG, Rao VC. Radioprotective activity of ficus racemosa ethanol extract against electron beam induced dna damage in vitro, in vivo and in silico. Int $\mathrm{J}$ Pharm Pharm Sci 2015;7:110-9.

44. Ashcroft M, Vousden KH. Regulation of p53 stability. Oncogene 1999; 18:7637-43.

45. Ashcroft M, Taya Y, Vousden KH. Stress signals utilize multiple pathways to stabilize p53. Mol Cell Biol 2000;20:3224-33.

46. Sadot E, Geiger B, Oren M, Ben-Ze'ev A. Down-regulation of betacatenin by activated p53. Mol Cell Biol 2001;21:6768-81.

47. Charni M,Aloni-Grinstein R, Molchadsky A, Rotter V. p53 on the crossroad between regeneration and cancer. Cell Death Differ 2017;24:8-14. 